\title{
An Examination of the Antimicrobial and Anticancer Properties of Mangosteen Pericarp Extracts
}

\author{
C. Gaillot \\ Ingenieurs Bio-industries
}

Saint Louis Polytechnic Institute of Cergy

Cergy

France
J. Sirdaarta and I.E. Cock

Environmental Futures Research Institute and School of Natural Sciences

Griffith University

Brisbane

Australia

Keywords: mangosteen, Jeg-3 choriocarcinoma, Anti-proliferative activity, Anticancer activity, Antibacterial activity, Toxicity.

\begin{abstract}
Garcinia mangostana (family Clusiaceae), commonly known as mangosteen, is a large tree native to tropical regions of Asia. Its fruit are highly prized for their pleasant taste. The fruit pericarp also has ethnobotanical uses in the treatment of a wide variety of diseases and medical conditions. G. mangostana fruit pericarp extracts were investigated for their ability to inhibit the growth of a panel of bacteria and fungi of medicinal importance. The extracts were also tested for their ability to block the proliferation of the Jeg-3 human choriocarcinoma cell line. All extracts displayed broad spectrum antimicrobial activity, inhibiting the growth of between $13(72 \%)$ and $15(83 \%)$ of the 18 bacterial species tested. In contrast, none of the fungal species were inhibited by the mangosteen extracts. Strong inhibitory activity was detected with minimum inhibitory concentration (MIC) values as low as $10 \mu \mathrm{g} / \mathrm{ml}$ against some bacteria. All extracts were effective against both Gram negative and Gram positive bacteria, although Gram negative bacteria were more sensitive. All extracts displayed anti-proliferative activity against Jeg-3 human choriocarcinoma cells, yet were non-toxic in the Artemia franciscana bioassay with LC50 values greatly in excess of $1 \mathrm{mg} / \mathrm{ml}$. The inhibitory bioactivity against a range of microbes, the anti-proliferative activity against Jeg-3 cells, as well as the lack of toxicity, indicate the potential for mangosteen in the discovery and development of new natural pharmaceuticals.
\end{abstract}

\section{INTRODUCTION}

Mangosteen (Garcinia mangostana Linn.) is a slow-growing evergreen tropical tree belonging to the family of Clusiaceae. It grows in tropical areas of Asia including India, Indonesia, Malaysia, Myanmar, Philippines, Singapore, Sri Lanka and Thailand, although it is thought to have originated in the Sunda Islands of Indonesia. The dark purple mangosteen fruit is highly prized for its flavour and is often known as 'the queen of fruit'. The fruit consists of a soft white edible pulp with a sweetly acidic flavour surrounded by a thick pericarp. Whilst the pericarp is inedible, it is sought after for its therapeutic properties. Southeast Asian traditional medicinal systems have utilised mangosteen pericarp in the treatment of wounds, skin infections and other skin disorders (eg. eczema), diarrhoea and dysentery, fever, urinary tract 
infections, arthritis and inflammation (Pedraza-Chaverri et al., 2008; Morton, 1987). Similarly, mangosteen pericarp is widely used in Indian Ayurvedic medicine in the treatment of cholera, diarrhoea, dysentery and inflammation (Pedraza-Chaverri et al., 2008). This study was undertaken to examine the therapeutic properties of $G$. mangostana. In particular, the antimicrobial properties of mangosteen pericarp extracts were evaluated against a panel of bacteria and fungi to examine the therapeutic potential of mangosteen extracts in the treatment of infectious diseases. This study also examined the anticancer properties of mangosteen by testing extracts against the Jeg-3 choriocarcinoma cell line (which has high level thioredoxin expression; Di Trapani et al., 1998). The toxicity of the mangosteen pericarp extracts was also examined to further determine their suitability for therapeutic usage.

\section{MATERIALS AND METHODS}

G. mangostana powder was bought from Rasyan Mangosteen, Thailand as an air dried ground powder. An amount of $1 \mathrm{~g}$ of plant material was weighed into each of four tubes and four different extracts were prepared by adding $50 \mathrm{ml}$ of methanol, water, ethyl acetate or chloroform respectively. All solvents were obtained from Ajax and were AR grade. Powdered material was extracted into each solvent for 24 hours at $4{ }^{\circ} \mathrm{C}$ with gentle shaking. The extracts were filtered through filter paper (Whatman No. 54) under vacuum, followed by drying by rotary evaporation in an Eppendorf concentrator 5301. The resulting dry extracts were weighed and redissolved in $10 \mathrm{ml}$ deionised water (containing 1\% DMSO).

\section{Qualitative phytochemical studies}

Phytochemical analysis of Garcinia mangostana extracts was conducted using previously described assays (Boyer and Cock, 2013).

\section{Antibacterial screening}

1. Test microorganisms. All microbial strains were obtained from Michelle Mendell and Tarita Morais, Griffith University, Australia. Stock bacterial cultures were subcultured and maintained in nutrient broth at $4{ }^{\circ} \mathrm{C}$. Stock fungal cultures were subcultured and maintained in Sabouraud broth at $4{ }^{\circ} \mathrm{C}$.

2. Evaluation of antimicrobial activity. Antimicrobial activity of all plant extracts was determined using a modified disc diffusion method (Cock and van Vuuren, 2013). Standard discs of ampicillin $(2 \mu \mathrm{g})$ and nystatin $(100 \mu \mathrm{g})$ were obtained from Oxoid Ltd. and served as positive controls for antibacterial and antifungal activity, respectively. Filter discs impregnated with $10 \mu \mathrm{l}$ of distilled water were used as negative controls.

\section{Minimum inhibitory concentration determination}

The minimum inhibitory concentrations (MIC) of the G. mangostana extracts were determined by the disc diffusion method, across a range of $5 \mathrm{mg} / \mathrm{ml}$ to $0.1 \mathrm{mg} / \mathrm{ml}$ (Winnett et al., 2014). The assay was performed as outlined for the spot assays and graphs of the zone of inhibition versus concentration were plotted for each extract. Linear regression was used to calculate the MIC values. 


\section{Screen for anti-Anticancer bioactivity}

1. Jeg-3 choriocarcinoma cell line. The Jeg-3 human choriocarcinoma cell line used in this study were originally obtained from American Type Culture Collection (Rockville, USA) by Dr Giovanna Di Trapani, Griffith University, Australia, and kindly donated for use in these studies. The cells were cultured in Roswell Park Memorial Institute (RPMI) 1640 medium (Life Technologies), supplemented with $20 \mathrm{mM}$ HEPES, $10 \mathrm{mM}$ sodium bicarbonate, $50 \mu \mathrm{g} / \mathrm{ml}$ streptomycin, $50 \mathrm{IU} / \mathrm{ml}$ penicillin, $2 \mathrm{mM}$ glutamine and $10 \%$ foetal calf serum (Life Technologies). The cells were maintained as monolayers in $75 \mathrm{ml}$ flasks at $37^{\circ} \mathrm{C}, 5 \% \mathrm{CO}_{2}$ in a humidified atmosphere until reaching approximately $80 \%$ confluence.

2. Evaluation of anti-Jeg-3 proliferative activity. For anti-proliferation studies, $1 \mathrm{ml}$ of trypsin (Sigma) was added to the culture flasks and incubated at $37{ }^{\circ} \mathrm{C}, 5 \% \mathrm{CO}_{2}$ for 15 min to dislodge Jeg-3 cells. The cell suspension was then transferred to a $10 \mathrm{ml}$ centrifuge tube and pelleted by centrifugation. The supernatant was discarded and the cells were resuspended in 9 $\mathrm{ml}$ of fresh medium. Aliquots of the resuspended cells ( $70 \mu 1$, containing approximately 5000 cells) were added to the wells of a 96 well plate. A volume of $30 \mu 1$ of the test extracts or cell medium (for the negative control) was added to individual wells and the plates were incubated at $37{ }^{\circ} \mathrm{C}, 5 \% \mathrm{CO}_{2}$ for 12 hours in a humidified atmosphere. A volume of $20 \mu \mathrm{l}$ of Cell Titre 96 Aqueous One solution (Promega) was subsequently added to each well and the plates were incubated for a further 3 hours. Absorbances were recorded at $490 \mathrm{~nm}$ using a Molecular Devices, Spectra Max M3 plate reader. All tests were performed in at least triplicate and triplicate controls were included on each plate. The anti-proliferative activity of each test was calculated as a percentage of the negative control using the following formula:

$$
\text { Proliferation }(\% \text { untreated control })=\left(\mathrm{A}_{c t} / \mathrm{A}_{c c}\right) \times 100
$$

where $A_{c t}$ is the corrected absorbance for the test extract (calculated by subtracting the absorbance of the test extract in medium without cells from the extract plus cell test combination) and $\mathrm{A}_{\mathrm{cc}}$ is the corrected untreated control (calculated by subtracting the absorbance of the untreated control in medium without cells from the untreated cell plus medium combination).

\section{Toxicity screening}

1. Reference toxins for biological screening. Potassium dichromate $\left(\mathrm{K}_{2} \mathrm{Cr}_{2} \mathrm{O}_{7}\right)$ (AR grade, Chem-Supply, Australia) was prepared as a $2 \mathrm{mg} / \mathrm{ml}$ solution in distilled water and was serially diluted in synthetic seawater for use in the $A$. franciscana nauplii bioassay.

2. Artemia franciscana nauplii toxicity screening. Toxicity was tested using a modified Artemia franciscana nauplii lethality assay (Cock and Ruebhart, 2009). Briefly a volume of $400 \mu 1$ of seawater containing approximately 41 (mean 40.8, SD 16.4, $\mathrm{n}=180$ ) nauplii were added to wells of a 48 well plate and immediately used for bioassay.

The plant extracts were diluted in seawater for toxicity testing and $400 \mu \mathrm{l}$ of the diluted plant extract and the reference toxins were transferred to the wells and incubated at $25 \pm 1{ }^{\circ} \mathrm{C}$ under artificial light. A negative control (400 $\mu$ l seawater) was run in at least triplicate for each plate. All treatments were performed in at least triplicate. The wells were checked at regular intervals and the number of dead counted. The nauplii were considered moribund if no movement of the appendages was observed within $10 \mathrm{sec}$. After $24 \mathrm{~h}$, all nauplii were 
sacrificed and counted to determine the total number per well. The LC50 with $95 \%$ confidence limits for each treatment was calculated using probit analysis.

\section{Statistical analysis}

Data are expressed as the mean \pm SEM of at least three independent experiments. One way ANOVA was used to calculate differences between control and treated groups with a $P$ value $<0.05$ considered to be significant.

\section{RESULTS}

\section{Liquid extraction yields and qualitative phytochemical screening}

Extraction of $1 \mathrm{~g}$ quantities of dried plant material with various solvents yielded dried plant extracts ranging from approximately $138 \mathrm{mg}$ to $387 \mathrm{mg}$ (Table 1). Phytochemical studies (Table 1) show that methanol and water extracted the widest range and largest amount of phytochemicals in this study. Both extracts showed moderate to high levels of total phenolics (water soluble and insoluble phenolics), triterpenoids and tannins, with moderate levels of saponins and flavonoids and low levels of alkaloids and anthraquinones. Similar classes of phytochemicals were detected in the ethyl acetate extract, although generally at lower levels. Alkaloids were only detected in the methanol extract and only at low levels. No alkaloids were detected in any of the extracts. The chloroform extract had high levels of water-insoluble phenolics, but showed only low levels of any other class of those phytochemicals screened.

\section{Antibacterial activity}

All extracts displayed broad spectrum inhibitory activity against Gram negative bacteria and Gram positive bacteria (Table 1). In general, the methanol and water extracts were better inhibitors of growth than were the other extracts. In contrast to bacterial growth inhibition, fungal growth was not susceptible to any of the mangosteen fruit pericarp extracts. Most of the extracts were effective at inhibiting microbial growth at low concentrations, with MIC values against the bacterial species that they inhibited often $<1000 \mu \mathrm{g} / \mathrm{ml}(<10 \mu \mathrm{g}$ impregnated in the disc), indicating the potent antimicrobial activity of these extracts. These MIC values compare favourably with the dosages of the pure standards ampicillin and nystatin which were tested using $2 \mu \mathrm{g}$ and $100 \mu \mathrm{g}$ per disc, respectively. The water extract was particularly potent, achieving MIC values as low as $10 \mu \mathrm{g} / \mathrm{ml}$ against $E$. aerogenes.

\section{Inhibition of cancer cell proliferation}

All extracts displayed potent inhibitory activity towards Jeg 3 cell proliferation (Table 2). The ethyl acetate extract was a particularly good growth inhibitor with an IC50 of 11.5 $\mu \mathrm{g} / \mathrm{ml}$, indicating its potential for cancer therapeutic development. Whilst less potent, the methanolic and aqueous extracts displayed moderately high anti-proliferative activity (IC50 values of approximately $44 \mu \mathrm{g} / \mathrm{ml}$ and $64 \mu \mathrm{g} / \mathrm{ml}$ respectively). In contrast, the chloroform extract exhibited a higher IC50 $(183 \mu \mathrm{g} / \mathrm{ml})$, indicating lower anti-proliferative activity. 


\section{Quantification of toxicity}

Table 2 shows the extract and control toxin concentrations required to achieve $50 \%$ mortality (LC50) at various times. As toxicity of crude plant extracts has previously been defined as 24 LC50 values $<1000 \mu \mathrm{g} / \mathrm{ml}$ (Cock and Ruebhart, 2009), the measured LC50 values indicate that all macadamia nut extracts were non-toxic.

\section{DISCUSSION}

The current study reports on the antimicrobial and anticancer activities of various mangosteen fruit pericarp extracts, and on their toxicity. Bacterial growth was inhibited in both Gram positive and Gram negative bacteria by the mangosteen pericarp extracts, although the Gram negative bacteria were substantially more susceptible. Previous screening studies against different bacterial species have also reported antibacterial activity for crude G. mangostana fruit pericarp extracts consistent with the MIC values seen in our study (Thomas and Veda, 2007; Chomnawang et al., 2005). The ability of plant extracts to inhibit the growth of both Gram positive and Gram negative bacteria has been previously reported for other plants that have a history of medicinal usage for the treatment of microbial diseases (Sautron and Cock, 2014; Chikowe et al., 2013). However, the greater susceptibility of the Gram negative bacterial species towards extracts of these species is noteworthy.

Potent anti-proliferative activity against Jeg-3 choriocarcinoma cells was noted for all of the mangosteen fruit pericarp extracts screened in this study, with IC50 values of approximately 44, 64, 12 and $184 \mu \mathrm{g} / \mathrm{ml}$ for the methanol, water, ethyl acetate and chloroform extracts respectively. This is particularly noteworthy as Jeg-3 cells produce high levels of thioredoxin (Di Trapani et al., 1998) and thus would be expected to be resistant to apoptosis induction. Our findings are consistent with previous studies examining the anticancer effects of mangosteen extracts against other cell lines. Aqueous mangosteen pericarp extracts exhibit potent anti-proliferative activity against K562 and Raji leukemia cell lines with IC50 values of approximately 61 and $160 \mu \mathrm{g} / \mathrm{ml}$ respectively (Chiang et al., 2004). The same study also reported low activity against P3HR1 and U937 leukemia cells. Furthermore, as extracts with LC50 values greater than $1000 \mu \mathrm{g} / \mathrm{ml}$ in the Artemia nauplii bioassay have been defined as being non-toxic (Cock and Ruebhart, 2009), all the mangosteen pericarp extracts were determined to be nontoxic (with $24 \mathrm{~h}$ LC50 values between approximately 2500 and 8500 $\mu \mathrm{g} / \mathrm{ml})$.

Our results indicate that the G. mangostana fruit pericarp extracts examined in this report are worthy of further study due to their antibacterial activity and ability to block cancer cell proliferation. Purification and identification of the bioactive components is needed to examine the mechanisms of action of these agents. Whilst the extracts examined in this report have potential as antimicrobial and anticancer agents, caution is needed before these compounds can be applied to medicinal purposes. In particular, further toxicity studies using human cell lines are needed to determine the suitability of these extracts for these purposes. 


\section{CONCLUSIONS}

The results of this study partially validate the traditional usage of $G$. mangostana fruit pericarp extracts in multiple traditional Asian medicinal systems to treat bacterial diseases and cancer, indicating that they are worthy of further study. Bioactivity-driven purifications of the active components and examination of the mechanisms of action of these agents is required.

\section{ACKNOWLEDGEMENTS}

Financial support for this work was provided by School of Natural Sciences, Griffith University. The authors are grateful to Dr Giovanna Di Trapani of Griffith University for the kind gift of the Jeg-3 cells used in these studies.

\section{Literature Cited}

Boyer, H. and Cock, I.E. 2013. Evaluation of the potential of Macademia integriflora extracts as antibacterial food agents. Pharmacog. Comm. 3 (3):53-62.

Chiang, L.C., Cheng, H.Y., Liu, M.C., Chiang, W. and Lin, C.C. 2004. In vitro evaluation of antileukemic activity of 17 commonly used fruits and vegetables in Taiwan. Lebensm. Wiss. Technol. 37:539-544.

Chikowe, G., Mpala, L. and Cock I.E. 2013. Antibacterial activity of selected Australian Syzygium species. Pharmacog. Commn. 3 (4):77-83.

Chomnawang, M.T., Sakagami, S.S., Nukoolkarn, V.S. and Gritsanapan, W. 2005. Antimicrobial effects of Thai medicinal plants against acne-inducing bacteria. J. Ethnopharmacol. 101:330-333.

Cock, I.E. and Kukkonen, L. 2011. An examination of the medicinal potential of Scaevola spinescens: Toxicity, antibacterial and antiviral activities. Pharmacog. Res. 3:85-94.

Cock, I., Mohanty, S., White, A. and Whitehouse, M. 2012. Colloidal silver (CS) as an antiseptic: Two opposing viewpoints. Pharmacog. Commn. 2(1):47-56.

Cock, I.E. and Ruebhart, D.R. 2009. Comparison of the brine shrimp nauplii bioassay and the ToxScreen-II Test for the detection of toxicity associated with Aloe vera (Aloe barbadensis Miller) leaf extract. Pharmacog. J. 1:98-101.

Cock, I.E. and van Vuuren, S.F. 2013. Anti-Proteus activity of some South African medicinal plants: Their potential for the treatment and prevention of rheumatoid arthritis. Inflammopharmacol. 21:DOI 10.1007/s10787-013-0179-3.

Di Trapani, G., Perkins, A. and Clarke, F. 1998. Production and secretion of thioredoxin from transformed human trophoblast cells. Mol. Hum. Reprod. 4 (4):369-375.

Morton, J. 1987. Fruits from Warm Climates. Creative Resource Systems Inc., Miami, USA. 304. 
Pedraza-Chaverri, J., Cárdenas-Rodriguez, N., Orozco-Ibarra, M. and Pérez-Rojas, J.M. 2008. Medicinal properties of mangosteen (Garcinia mangostana). Food Chem. Toxicol. 46:3227-3239.

Sakagami, Y., Iinuma, M., Piyasena, K.G.N.P. and Dharmaratne, H.R.W. 2005. Antibacterial activity of a-mangostin against vancomycin resistant Enterococci(VRE) and synergism with antibiotics. Phytomed. 12:203-208.

Sautron, C. and Cock, I.E. 2014. Antimicrobial activity and toxicity of Syzygium australe and Syzygium leuhmanii fruit extracts. Pharmacog. Commn. 4 (1):53-60.

Thomas, J. and Veda, B. 2007. Screening of ten Indian medicinal plants for their antibacterial activity against Shigella species and Escherichia coli. African J. Infect. Dis. 1(1):36-41.

Winnett, V., Boyer, H., Sirdaarta, J. and Cock, I.E. 2014. The potential of Tasmannia lanceolata as a natural preservative and medicinal agent: Antimicrobial activity and Toxicity. Pharmacog. Commn. 4(1):42-52.

\section{$\underline{\text { Tables }}$}

Table 1: The mass of dried extracted material, the concentration of extracts after resuspension in deionised water, qualitative phytochemical screenings and MIC's $(\mu \mathrm{g} / \mathrm{ml})$ of solvent extractions.

\begin{tabular}{|c|c|c|c|c|}
\hline & Methanol & Water & $\begin{array}{c}\text { Ethyl } \\
\text { Acetate }\end{array}$ & Chloroform \\
\hline Mass of dried extract (mg) & $\begin{array}{c}386.9 \pm \\
16.5\end{array}$ & $\begin{array}{c}333.8 \pm \\
13.3\end{array}$ & $138.2 \pm 4.0$ & $176.0 \pm 4.2$ \\
\hline $\begin{array}{l}\text { Resuspended extract } \\
\text { concentration }(\mathrm{mg} / \mathrm{ml})\end{array}$ & $38.7 \pm 1.7$ & $33.4 \pm 1.3$ & $13.8 \pm 0.4$ & $17.6 \pm 0.4$ \\
\hline \multicolumn{5}{|c|}{ Qualitative phytochemical screens } \\
\hline Total phenolics & +++ & +++ & +++ & + \\
\hline Water soluble phenolics & +++ & +++ & +++ & + \\
\hline Water insoluble phenolics & +++ & +++ & +++ & +++ \\
\hline Cardiac glycosides & - & - & - & - \\
\hline Saponins & ++ & - & - & - \\
\hline Triterpenoids & +++ & ++ & + & - \\
\hline Polysterols & - & - & - & - \\
\hline Alkaloids (Mayer test) & + & - & - & - \\
\hline Alkaloids (Wanger test) & + & + & - & - \\
\hline Flavanoids & ++ & ++ & +++ & + \\
\hline Tannins & +++ & +++ & ++ & - \\
\hline Anthraquinones & + & + & - & - \\
\hline \multicolumn{5}{|l|}{ Gram-negative bacteria } \\
\hline A. faecalis & - & $\begin{array}{c}4537 \pm \\
236\end{array}$ & - & - \\
\hline A. hydrophillia & $\begin{array}{c}4330 \pm \\
199\end{array}$ & $1265 \pm 49$ & - & - \\
\hline E. aerogenes & $52 \pm 3$ & 10 & $84 \pm 3$ & $503 \pm 17$ \\
\hline E. coli & $840 \pm 33$ & $834 \pm 35$ & $711 \pm 27$ & $1208 \pm 66$ \\
\hline
\end{tabular}




\begin{tabular}{lcccc} 
K. pneumoniae & $48 \pm 2$ & $180 \pm 9$ & $72 \pm 6$ & $399 \pm 15$ \\
P. mirabilis & $163 \pm 9$ & $322 \pm 14$ & $19 \pm 1$ & $1054 \pm 57$ \\
P. aeruginosa & $647 \pm 25$ & $1610 \pm 61$ & $708 \pm 23$ & $3200 \pm 106$ \\
S. newport & $344 \pm 24$ & $673 \pm 32$ & - & $1350 \pm 72$ \\
S. marcenscens & $1864 \pm 67$ & $2385 \pm 88$ & $1128 \pm 56$ & $1310 \pm 69$ \\
S. sonnei & $583 \pm 26$ & $1534 \pm 94$ & $776 \pm 39$ & $2855 \pm 83$ \\
Gram-positive bacteria & & & & \\
B. cereus & $1670 \pm 82$ & $2477 \pm 64$ & $1127 \pm 61$ & $1338 \pm 74$ \\
E. faecalis & $3315 \pm 90$ & $5950 \pm$ & $1718 \pm 84$ & $3428 \pm 121$ \\
S. aureus & $1202 \pm 44$ & $1422 \pm 74$ & $2549 \pm 97$ & $3745 \pm 147$ \\
S. epidermidis & $238 \pm 7$ & $343 \pm 16$ & $1340 \pm 77$ & $1873 \pm 83$ \\
S. pyogenes & $1137 \pm 45$ & - & $1280 \pm 55$ & $1655 \pm 57$ \\
\hline
\end{tabular}

+++ indicates a large response; ++ indicates a moderate response; + indicates a minor response; - indicates no response in the assay. Numbers indicate the mean ( \pm SEM) MIC values of at least triplicate determinations.

Table 2: The IC50 ( $\mu \mathrm{g} / \mathrm{ml})$ of Jeg-3 cells and LC50 for brine shrimp nauplii exposed to $G$. mangostana fruit pericarp extracts and controls.

\begin{tabular}{lccc} 
& \multirow{2}{*}{ Extract } & $\begin{array}{c}\text { IC50 }(\boldsymbol{\mu g} / \mathbf{m l}) \text { of } \\
\mathbf{J e g - 3} \text { cells }\end{array}$ & \multicolumn{2}{c}{$\begin{array}{c}\text { Brine shrimp LC50 } \\
(\boldsymbol{\mu g} / \mathbf{m l})\end{array}$} \\
\cline { 3 - 4 } & & $\mathbf{2 4}$ hours & $\mathbf{4 8}$ hours \\
\hline Methanol & $43.9 \pm 1.8$ & $5366 \pm 440$ & $2250 \pm 163$ \\
Water & $64.2 \pm 2.4$ & $2564 \pm 185$ & $2238 \pm 187$ \\
Ethyl Acetate & $11.5 \pm 0.7$ & $8428 \pm 506$ & $5606 \pm 304$ \\
$\begin{array}{l}\text { Chloroform } \\
\text { Negative Control (seawater) }\end{array}$ & $183 \pm 8.4$ & - & - \\
$\begin{array}{l}\text { Positive Control (potassium } \\
\text { dichromate) }\end{array}$ & - & - & - \\
\hline
\end{tabular}

Numbers indicate the mean ( \pm SEM) IC50 and LC50 values of at least triplicate determinations. - denotes values that were not obtained as no significant inhibition was recorded. $\mathrm{NT}=$ not tested. 